For well over twenty years I have been keeping a record of the different species of birds seen each year. It is very interesting to go back over rny annual lists and note the regularity with which our feathered friends arrive in the Spring, the occasional very late coming of some common bird, or the fact that sone years I failed to see it altogether. My records show quite a number of birds that I have observed only once or twice in this locality.

Perhaps the rarest bird that came within the range of my field glasses was the Cinnamon Teal. One evening while my wife and I were sitting in our car, admiring the beauty of a mixed flock of ducks swimming around in a slough inside the town limits, I noticed an unusual bird on the far side of the pond. Grabbing my binoculars, I saw it was about the size of a Bluewinged Teal, but had a general reddish coloration. I recognized it at once as a Cinnamon Teal Drake. The same week I read in the Chickadee Notes that one of these rare/ducks had been seen in Manitoba. This bird, common in upper Culifornia, Oregon and lower British Columbia, has appeared several times in Saskatchewan but, of course, is a straggler, entirely out of its normal range.

The greatest surprise I ever received and perhaps the greatest thrill, was in 1943. A woman telephoned me that hundreds of swallows were roosting on the telephone lines back of her home, and I trotted over to have a look at then. I was standing near the garage, both doors of which were open, when I noticed a small bird flitting around inside the building, and its peculiar markings at once diverted all my inter est from the swallows. It was clearly one of the sparrow family, but what amazed me was a bright yellow spot on the breast. One would naturally think that it must be a warbler, but the cone-shaped bill and general set-up of the bird eliminated that species. The pretty fellow flew from one place to another in the garage, not seeming to notice the open doors, and on several occasions perched close to me for half a minute at a time.

I had no idea nat it was but sonetime afterwards, with the assistance of A.G. Lawrence, Editor of "Chickadee Notes" in the Winnipeg Free Press, I identified the bird as a Dickcissel, commonly called a little Meadowlark. Taverner in "Birds of Canada" says it is very rare in this country.

I have seen Turnstones only two or three times, but once spent a most enjoyable half hour watching a pair feeding at the lake near the C.N.R. Dan here. The way they manage the stones with their stout bills is remarkable. No laborious prying but a quick flip and the stone, sometines two or three inches in diameter, flies into the air and turns over. These birds are very handsome fellows with their striking markings of brown, black and white, and present a very pretty picture on the ground, and perhaps even more so in flight.

Anong the nost beautifuI sights that have ever delighted my eyes were flocks of Golden Plovers. I have seen these birds only occasionally, but twice have run across a flock of at least seventy-five. They are gorgeous, and to watch them whem 1 and turn in flight is in itself a fine experience. Last year my wife and I ran across one of these large flocks on the edge of a slough, a short distance from a house on the outskirts of town. They allowed us to approach within a hundred feet of them, and I think we might have gone much nearer if a dog had not put them to flight.

Avocets, anong the most beautiful of our wading birds, are to be found in numbers around the alkali sloughs of Alberta and Western Siskatchewan, but are rare here. My notebook records only one, a bird which I saw standing on Indian'Point at Cruoked Lake, about five years ago. 
A real rarity is the Red-backed Snipe, which is easily recognized by the black patch on its beIly. There are very few records of this snipe in the province. I have only seen it once, when I was lucky enough to find a small flock probing the mud at the C.N.R. Lake.

The first pair of Arkansas Kingbirds appeared in Melville in 1924, and for four years running, nested behind a can on an electric light pole at the back of our yard. Mr. Mitchell, then Provincial Naturalist, told me it was the farthest north record in the province for this bird. I am quite satisfied that the same pair came back each time because I kept a sharp lookout and did not see a single other member of this species anywhere in the district. They raised a fanily each year, with some assistance from me, as I frequently had to pick the young birds off the lawn and place them in a tree. These Kingbirds are now quite common here, and are reported much farther north than Melville.

This, however, seems to be about the northern range of the Lark Bunting, so common in the southern part of the province. I have three records of these birds and curiously saw them twice, several years apart, on the grounds of the Miller School the last record being in 1944.

As I look over my notes, many interesting recollections crowd my memory. I am reminded of the time I identified sixteen kinds of wading birds, feeding on a mud flat near here, without moving from the stone on which I perched, and of another occasion when I saw eight kinds of waders, two of them very rare, all gathered at a tiny slough within the town Iimits. Only once have I seen a flock of Purple Finches, but on the 26th day of April, 1942, two girls brought me an injured male, who still enjoys my hospitality and earns his keep many times over with his melodious songs.

I am not likely to forget the time when I pushed my way through the tangled brush on a small island in a lake north of Punnichy, and found two young turkey buzzards. Although the birds were fully grown they had not discovered their power of flight, having never left the vicinity of their nest which was under a fallen log among a thick growth of trees. With the help of two friends, who were with me, we caught the birds easily and while one of their parents watched with some concern from the top of a tall, dead poplar, we set them on the branch of a tree by the lakeshore, preparatory to photographing them. One of my companions, who possessed the camera, had told me to leave mine at the cottage because he had an exceptionally good one. Then we were all ready to take the priceless picture he discovered the distressing fact that he had forgotten to load the camera with film. I could have shot him then and there, and sometimes think I shall do it yet. Never again will I have an opportumity to secure such a most unusual bird photograph.

\section{YORKTON MIGRATION RECORDS FOR MARCH}

That the arrival of the first migrant birds is governed largely by weather conditions was proved without doubt this year, when spring-like temperatures in midMarch brought an amazing array of birds back to the prairies two weeks or more ahead of their usual date of return. Not since 1938 has such an early migration occured. Up to March 31 our Yorkton list was - HORNED IARK, Feb. 28. MAFSH HAWK, MOUNTAIN BLUEBIRD, ROBIN, Narch 18. MEADOWLARK, BREWER'S BLACKBIRD, CANADA GOOSE, MALLARD, March 19. SLATE-COLORED JUNCO, March 20. KILLDEER, RED-TAILED HABK, AMERICAN ROUGHLEG HATK, March 23. RED-WINGED BLACKBIRD, PINTHIL, TREE SFARROT, EISTERN BLUEBIRD, March 25.

Snow and sleet storms checked further migration in the Yorkton area the last week of the month, but in Manitoba an all-time record of 32 birds had been reported up to March 28. 